\title{
Morphology and zoogeography of the burrower-like gammarid Gammarus koshovi (Bazikalova, 1946) (Crustacea, Amphipoda, Gammaridae) - An overlooked and poorly known species in the Siberian fauna
}

\author{
Dmitry SIDOROV ${ }^{1, *}$, Elena YALYSHEVA ${ }^{2} \&$ Mariana SHARYI-OOL $^{3}$ \\ ${ }^{1,3}$ Federal Scientific Center of the East Asia Terrestrial Biodiversity, \\ Russian Academy of Sciences, Vladivostok 690022, RF. \\ ${ }^{2}$ Municipal State Educational Institution "Osinovskaya shkola”, Osinovyy Mys 663457, RF. \\ *Corresponding author: biospeorossica@gmail.com \\ ${ }^{2}$ Email: ona_vita@rambler.ru \\ ${ }^{3}$ Email: sharyiool@biosoil.ru \\ ${ }^{1}$ urn:1sid:zoobank.org:author:55C1264F-67C0-4C3F-8E6B-ECE1E821457B \\ ${ }^{2}$ urn:Isid:zoobank.org:author:88AB67D2-1F97-4A2C-8121-362132FCF07C \\ ${ }^{3}$ urn:lsid:zoobank.org:author:9DE31FF0-0660-4980-B819-63305D609CAC
}

\begin{abstract}
A comprehensive survey of several lakes in the Tuva Republic of Russia yielded, besides the ubiquitous Gammarus lacustris, the discovery of a small freshwater, lacustrine amphipod not previously recorded in this area. A comparative study of the Tore-Khol Lake gammarid population, probably conspecific with Gammarus koshovi (Bazikalova, 1946) originating from Khubsugul Lake, was conducted. The species, G. koshovi, is characterized by a specific habitus: a small-sized compact body, all limbs shortened, carpi of pereopods (PIII and PIV) reduced, coxal plates broad, and pereopod dactyli sturdy. It has been suggested that juveniles of the euryoecious G. lacustris or other large species could be confused with the relatively small G. koshovi. Consequently, we decided to present the distribution of gammarid species throughout south Siberia and Mongolia, referring to the sequences of works primarily by Soviet authors, which may be hard to access by international readers. We discuss affinity with related groups, distribution, and ecology of G. koshovi to better understand their evolution. Additionally, the zoobenthic species diversity of widely represented groups in the ecosystems of Tore-Khol Lake is briefly reviewed. An identification key for the Siberian Gammarus with 10 species is provided.
\end{abstract}

Keywords. Malacostraca, taxonomy, Uvs Nuur Basin, Mongolia, first record.

Sidorov D., Yalysheva E. \& Sharyi-Ool M. 2021. Morphology and zoogeography of the burrower-like gammarid Gammarus koshovi (Bazikalova, 1946) (Crustacea, Amphipoda, Gammaridae) - An overlooked and poorly known speciesintheSiberianfauna.EuropeanJournalofTaxonomy 774:178-199.https://doi.org/10.5852/ejt.2021.774.1541

\section{Introduction}

The territory at the southern end of Central Siberia is rich in various mountain pools (more than 430 lakes) lying within the Sayan Province of the Lena-Yenisei subregion of the Palearctic (Leontyev 1957). The 
fluctuating geological history of the region (Misar 1997) and a significant variety of natural landscapes (Sanders et al. 2021) created a wide variety of aquatic biotopes (rivers, springs, takyrs / playas) and ephemeral rivers, as well as a wide variety of invertebrate species that inhabit them. However, it should be noted that the amphipod fauna of the southern region of Central Siberia, and especially Tuva, is practically unknown (Dgebuadze et al. 2010; Kirova 2019). Currently, our study is a first report for more than a century of amphipod research in Siberia.

The genus Gammarus J.C. Fabricius, 1775 is a large Holarctic/Sino-Indian epigean/subterranean group of amphipods that is typically found to be morphologically monotonous at high latitudes (Culver et al. 1995), with a number of distinctly divergent narrowly localized endemic species at the southern border of the range (Sidorov et al. 2018; Zheng et al. 2020). However, the historical reasons for this distribution are not entirely known. Despite the obvious inconsistencies in morphological distances between recent species and paraphyly within the group, the genus Gammarus reveals a certain unity and is known from at least the Oligocene-Eocene era (Hou et al. 2011). Earlier, in a series of publications, it was shown that the amazingly diverse endemic amphipod fauna of Baikal Lake, consisting of more than 354 species (Takhteev 2019), had radiated from a putative Gammarus-like ancestor in the Oligocene (28 Mya), coinciding with the formation of the lake (Ogarkov et al. 1997; Sherbakov et al. 1999; MacDonald et al. 2005; Hou \& Sket 2016).

As part of the inventory of the genus Gammarus J.C. Fabricius, 1775 inhabiting Siberia, samples from three different lakes of Tuva were collected. Two were small limnetic pools containing the ubiquitous Gammarus lacustris G.O. Sars, 1863, whereas in the dune subsaline lake Tore-Khol (also known as Döröö Nuur), a population of a poorly known species, Gammarus koshovi (Bazikalova, 1946) (sometimes misspelled as 'kozhovi', 'kozhowi,' or 'kozovi'), was apparently discovered. This species was described by A.Ya. Bazikalova in 1946 and originally placed in the now defunct genus Rivulogammarus S. Karaman, 1931. Type material of G. koshovi was either lost or not deposited, and the original description of the species by Bazikalova (1946) was so lacking in detail that its correct taxonomic status has remained problematic. It is noteworthy that G. koshovi was previously known only from the Mongolian Lake Khubsugul (Hövsgöl) that holds some endemic species of the purely Baikalian flocks (Kozhova et al. 1994; Martens \& Segers 2009) and its discovery in Lake Tore-Khol not only significantly expanded its range, but also raised additional questions.

Lake Tore-Khol is located in the northeastern part of the Ubsunur Basin (1148 m a.s.1.), $20 \mathrm{~km}$ south of Erzin. The lake was formed as a result of damming one of the tributaries of the Tes-Khem River by a ridge of moving sands, the Eder-Elesin. The dimictic steppe lake has exclusively subterranean inflow and an underground outflow, dominance of picoplanktic cyanobacteria, and strong calcite precipitation (Walther et al. 2020). It is oligotrophic, with a tendency towards being mesotrophic at the drainage area, with the following properties: total area $72 \mathrm{~km}^{2}$, approximately 7 m mean depth (max. $26-27 \mathrm{~m}$, according to some sources $38.8 \mathrm{~m}$ ), slightly subsaline $(0.6-0.7 \mathrm{~g} / \mathrm{L}), \mathrm{Mg} / \mathrm{Ca}-\mathrm{HCO}_{3}$ type, $\mathrm{T} 18.5^{\circ} \mathrm{C}$ (at max. depth $\mathrm{T} 6^{\circ} \mathrm{C}$ ), conductivity $0.71 \mathrm{mS} / \mathrm{cm}$, and $\mathrm{pH} 8.85-9.2$. It has sandy sediments with a different silting thickness overgrown with Chara sp. and Potamogeton pectinatus L., and a wide reed belt of Phragmites australis (Cav.) Steud. in places. Fishes include Oreoleuciscus sp. and Esox lucius Linnaeus, 1758 (artificially populated) (Zaika \& Makarov 2000; Flößner et al. 2005; Paul 2012; Dulmaa 2013; Kalnaya et al. 2018). This is the only lake declared in 1982 as a natural monument of republican significance with some areas later included in the protected zone of the 'Ubsunurskaya Kotlovina' Biosphere Reserve - a World Heritage Site of UNESCO since 2003 (Arakchaa \& Laidyp 1994).

Considering the importance of finding this species in constructing the general zoogeography of the genus Gammarus, we also attempted to provide a brief description of the freshwater fauna of Tore-Khol Lake in highlighting the common species with Khubsugul. 


\section{Historical review}

In 1851, J.F. Brandt reported on Gammarus in the Nachiki hot spring basin on E Kamchatka, which he believed was indistinguishable from Gammarus pulex (De Geer, 1778) (Brandt 1851). Gammarus ermanni Milne-Edwards, 1840 was mentioned among others reported in Kamchatka's thermal spring by H. Milne-Edwards in 1840, and was subsequently assigned to the genus Crangonyx Spence Bate, 1859 (Bate 1862; Karaman 1991). In a historical retrospective for Siberia, the indication of the binomial name Gammarus pulex is not unexpected. For example, a wide geographical distribution of this species was reported by R.K. Maak (1886) according to the results of the expedition of 1853-1855 to Angara, Lena, Vilyui, in the Ural region, Pyasina (Taimyr), in the vicinity of Olenek, beyond the Arctic Circle (see also Gerstfeldt 1858). Probably the binomen 'Gammarus pulex' was used as a collective name for any species of Gammarus, Eulimnogammarus Bazikalova, 1945, or Pallasea Spence Bate, 1862, and even Synurella Wrześniowski, 1877 that are usually common in these areas (see Stebbing 1906; Martynov 1930; Lepneva 1933). Later, in Mongolia, B.I. Dybowsky (1901) found G. pulex off the northern shore of Lake Khuvsgul, later referred to as Gammarus lacustris G.O. Sars, 1863 (Karaman 1991). In addition to this species, two more are known from Lake Khubsugul: Gammarus koshovi Bazikalova, 1946 (Erbaeva et al. 1990; Kozhova et al. 1994) and Gammarus hanhi Safronov, 2006 (Kozhova et al. 2000; Safronov 2006).

Studies of the hydrobiology of the lakes of the Ubsunur Basin do not cover an extended period. On the fauna of gammarids inhabiting the freshwater lakes of the Ubsunur depression, in particular Tore-Khol Lake, the information is either absent (Zaika 1993; Zaika \& Makarov 2000) or short (Dolgin \& Yalysheva 2008; Yalysheva 2010). Paul (2012) provides data on the euryhaline G. lacustris that stands as a typical component of the bottom fauna in salt lakes. In general, it should be noted that G. lacustris (partially identified as 'Gammarus sp.', 'Gammaridae', or 'gammarids') is a permanent component of the various aquatic biotopes of Tuva and Mongolia, often dominating the lotic and lentic communities (Dulmaa 1979; Gundriser et al. 1986; Shcherbina \& Ayuushsuren 2007; Kosterin \& Zaika 2011; Maasri \& Gelhaus 2012; Dgebuadze 2013; Matafonov 2014; Ayuushsuren \& Shcherbina 2015; Prokin et al. 2019); however, despite the identification of this species, its morphological and genetic profile remains unknown.

Other species of the genus Gammarus in Siberia, not mentioned above, that are known include: Gammarus korbuensis Martynov, 1930; Gammarus teletzkensis Martynov, 1930; Gammarus angulatus (= Gammarus ocellatus angulatus Martynov, 1930) from the mountain river Korbu and Teletskoye Lake; Gammarus angustatus Martynov, 1930 from the stream in the Inya River basin, Ob' River near Novosibirsk (Martynov 1930); Gammarus pellucidus Gurjanova, 1930 from the Ladeysky riffle at the Yenisey (sandbank) (Gurjanova 1930); Gammarus barnaulensis Schellenberg, 1937 (locus typicus is unknown), which A. Schellenberg indicated from Barnaul (Tomsk) in lakes, Burgusutai (W Siberia), which has led to confusion (Schellenberg 1937); Gammarus dabanus Tachteev \& Mekhanikova, 2000 from mountain streams of the northern macroslope of the Khamar-Daban Ridge (Tachteev \& Mekhanikova 2000); a suggested juvenile specimen of Gammarus sp. in Gurjanova (1930) from the Yenisey near Nyasha and a channel of the Yenisei near Khudonogovo (Gurjanova 1930).

\section{Material and methods}

\section{Sampling}

Specimens of gammarids were collected with a Petersen bottom grab sampler and a common hand net in three lakes of the territory of the Tuva Republic of Russia (see Fig. 1): Tore-Khol Lake, a small freshwater lake near Shara-Nur Lake and 'Dashtyg' alpine lake (see below). Samples were fixed and stored in a ca $80 \%$ ethanol solution. 
SIDOROV D. et al., Gammarus koshovi (Baz.) from Ubsunur Hollow

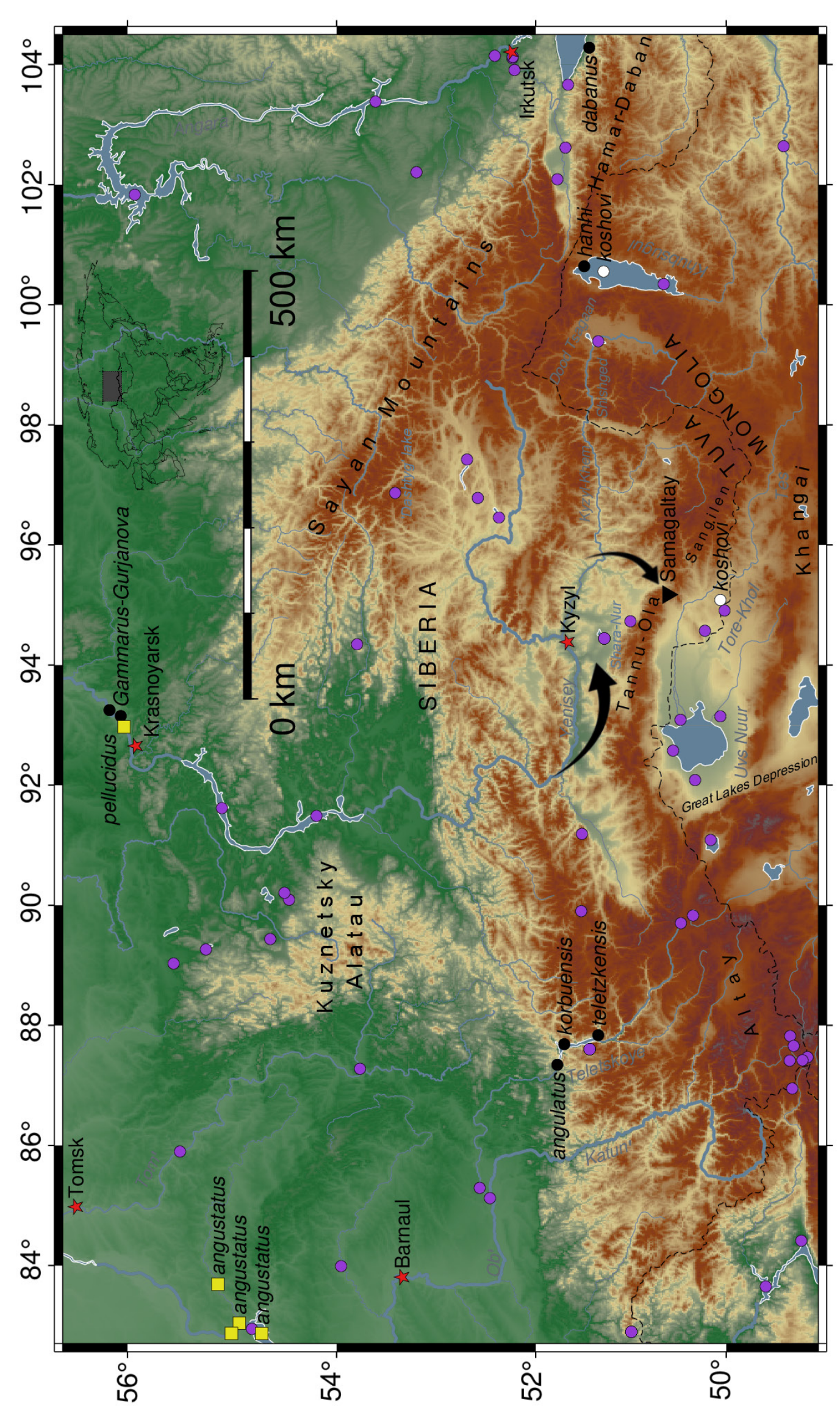

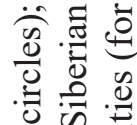

全.

릴

o

雪湾

$\overline{3} \geq$

焉: 恶 $\frac{0}{0}$

吾.

范

$\frac{\pi}{8} \frac{0}{0}$

궁 흥

音䒿

.

융

$\therefore$ -

苟出

त

후

ص ㄹ

$\checkmark$ 志

के है चा

원

৩ن

. 娄

㐘 क

.$\Xi \frac{0}{0}$ 를

등

긍 응

$\stackrel{?}{\exists}$

을

雳

0 \%

可

产

ई

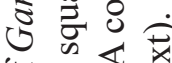

43

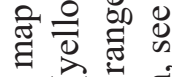

记

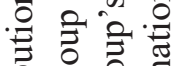

를

. 옹

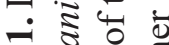

잉 


\title{
Morphology
}

Specimens were dissected using a dissecting microscope Lomo MBS-9 and mounted on microscope slides in polyvinyl lactophenol (PVL) and stained with methylene blue (Sigma-Aldrich Company, Inc.); dissected appendages were then covered with a coverslip and edged by clear nail polish. Prior to dissection, body length (BL) was recorded by holding the specimen straight and measuring the distance along the dorsal side of the body from the base of the first antennae to the base of the telson. All pertinent morphological structures were drawn using a Carl Zeiss NU-2 compound microscope equipped with a drawing device as modified by Gorodkov (1961). The nomenclature for setal patterns on article 3 of the mandibular palp follows the standard described by Karaman (1970) and Stock (1974). A geographical map (Fig. 1), with the location of the sampling sites, was constructed with the open source software Generic Mapping Tools, GMT ver. 4.5.14. The description given here is based on the type series which is deposited in the private collection of D.A. Sidorov (prefix DAS).

\section{Results}

\section{Taxonomy}

\author{
Subphylum Crustacea Brünnich, 1772 \\ Class Malacostraca Latreille, 1802 \\ Subclass Eumalacostraca Grobben, 1892 \\ Superorder Peracarida Calman, 1904 \\ Order Amphipoda Latreille, 1816 \\ Superfamily Gammaroidea Latreille, 1802 (Bousfield 1977) \\ Family Gammaridae Leach, 1814 \\ Genus Gammarus J.C. Fabricius, 1775
}

Gammarus koshovi (Bazikalova, 1946)

Figs 2-5

Rivulogammarus koshovi Bazikalova, 1946: 677, text-fig. (original description).

Rivulogammarus koshovi-Barnard 1958: 72. — Karaman 1991: 41.

Gammarus koshovi - Barnard \& Barnard 1983: 467. — Erbaeva et al. 1990: 56. — Kozhova et al. 2000: 104. - Safronov 2006: 210.

Diagnosis (both sexes)

Compact, small-sized amphipod with well-developed eyes; coxal plates spacious (especially coxae 4 and 5); appendages comparatively short; antennae short and stout; peduncle articles 1-3 of antenna I comprise $33 \%$ of its total length, accessory flagellum 2-segmented with terminal article greatly reduced; antenna II with rare long setae on ventral face, males with calceoli; pereopods III and IV with clusters of setae on articles 4-6 posteriorly, carpi shortened; pereopod dactyli III-VII strong; uropod III endopodite somewhat shorter than exopodite, all margins with mix of setae of different length. $\mathrm{BL}=8.0 \mathrm{~mm}$ (우 ),

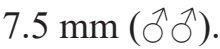

\section{Material examined (new records)}

RUSSIA - Tuva Republic $\cdot 2$ 우 $(\mathrm{BL}=$ ca $8.0 \mathrm{~mm})$; Tore-Khol Lake, isthmus; 50 02'42.6" N, 94 59'53.5" E; 6 m depth; 24 Jun. 2013; E.N. Yalysheva leg.; silted sand; DAS 16-013 • 2 juv. (BL = ca $5.0 \mathrm{~mm}$ ); near Tore-Khol Lake, not far from recreation center; $50^{\circ} 06^{\prime} 02.4^{\prime \prime} \mathrm{N}, 95^{\circ} 08^{\prime} 50.5^{\prime \prime} \mathrm{E}$; 7-8 m depth; 14 Aug. 2011, 27 Jun. 2015; E.N. Yalysheva leg.; silt; DAS 16-013 • 1 §ै (BL = ca 7.5 mm); Sharlaa; 5001'32.6" N, 9503'28.4" E; 3 m depth; 13 Aug. 2011; E.N. Yalysheva leg.; silted sand; DAS $16-013 \cdot 1$ o $(\mathrm{BL}=\mathrm{ca} 8.0 \mathrm{~mm})$; same collection data as for preceding; DAS $16-013 \cdot 2 \mathrm{juv} .(\mathrm{BL}=\mathrm{ca}$ 
$5.0 \mathrm{~mm})$; same collection data as for preceding; DAS $16-013 \bullet 1$ q $(\mathrm{BL}=$ ca $8.0 \mathrm{~mm}$, damaged $)$; site Yurty; 5004'44.6" N, 9508'38.5" E; 2 m depth; 28 Jun. 2015; E.N. Yalysheva leg.; silted sand; DAS 16-013.

\section{Description}

\section{Female}

Size. $\mathrm{BL}=8.0 \mathrm{~mm}$ (oostegites developed, setose, bearing 13-15 small-sized eggs).

GeNerAl BODY MORPHOLOGY (Figs 2A, 3A, 4G, 5A-B). Body stout, clearly setose with minute setules. Head with inferior antennal sinus moderate, subrounded, eyes pigmented. Pleon armed with dorsal setae. Coxal plates I-IV broad, lateral margins strongly overlap neighboring plates, distal margins rounded, with 2 short setae each, coxae II-III tapering distally, coxa IV lobate; coxal plates V-VII broad (especially, plate V). Coxal gills II-VII stalked and saccular, coxal gill VII smallest. Oostegites II-V (brood plates) of gammarid shape, well developed, oblong, plates II-IV broad, plate V the smallest. Posterior margin of epimeral plates I and II convex, not produced, with 3 setules each, distoposterior corner of plate I small, slightly produced, ventral margin with cluster of setae distoanteriorly; distoposterior corner of plate II strongly produced, with 4 long setae distoanteriorly; plate III strongly produced, but less than plate II, only with 2 spines on ventral margin and 3 long setae distoanteriorly. Urosomites with mediodorsal elevations, armed with groups of 2 spines and $1-3$ setae, spine formula I-III is: $2-2-2 / / 2-2-2 / / 2-0-2$. Telson shorter than uropod III peduncle; its width $88 \%$ of length, completely cleft, lobes apically with 2-3 notched spines accompanied by 3 long setae, laterally 1 spine or seta.

Antennae (Figs 2A, 3B-C). Antenna I 40\% of body length, peduncle articles in relation 1:0.6:0.35, flagellum of 17 articles, which are approximately twice as long as wide; accessory flagellum of 2 articles (1 long +1 reduced); peduncle articles with short setae on ventral face and apically, articles of main flagellum with short setae, each flagellar article bearing minute aesthetasc, shorter than setae. Antenna II $67 \%$ of antenna I length, peduncle articles (4-5) slightly longer than flagellum; peduncle articles 4-5 bearing rare long setae on ventral face and short setae in 10 clusters along their entire lengths; flagellum modestly equipped with short setae, no calceoli.

MoUTH PARTS (typical gammarid, Fig. 3D-K). Mandibular palp with article 2 the longest, with 9 stiff setae, article 3 bearing 3 A-setae, 3 B-setae, 16 D-setae and 4 E-setae. Maxilla I asymmetric, palps broad, apically with ca 5 or 6 strong spines accompanied by thin setae; outer lobe with 12 subequal pectinate spines with ca 6 denticles each. Maxilla II inner plate with oblique row of 30 plumose setae on inner margin. Maxilliped basal endite (= inner plate) with 3 simple strong cuspidate spines on distal margin (+1 spine located subdistally); rest without peculiarities.

GNathopods (Fig. 2B-C). Gnathopod I basis stout with long simple setae on anterior and posterior margins; carpus (article 5) triangular, $0.7 \times$ as long as propodus; propodus ovate, palm oblique, straight with cutting margin developed (no spines on medial face) and armed with 4 distally notched spines at defining angle; posterior margin as long as palm, bearing 4 sets of moderate setae; dactylus with 1 seta on outer face. Gnathopod II larger than gnathopod I; basis stout with long simple setae on anterior and posterior margins; carpus (article 5) $0.73 \times$ as long as propodus; propodus narrow, subrectangular, palm subtransverse, slightly concave, with cutting margin developed (spines on medial face lacking) and armed with 2 distally notched spines at defining angle; posterior margin twice as long as palm with ca 5 sets of setae; dactylus similar to that of gnathopod I.

Pereopods (Fig. 4A-E). Pereopods III-IV subsimilar, but pereopod III densely covered with sets of moderate (as long as article widths) setae along posterior margins of articles 4-6; carpi (articles 5) reduced, about $0.6 \times$ as long as corresponding propodus, each with 1 set of very long setae apically. Pereopods $\mathrm{V}-$ VII strong, subsimilar, pereopod VI as long as pereopod VII; basipodites shortened, besides basipodite VII 


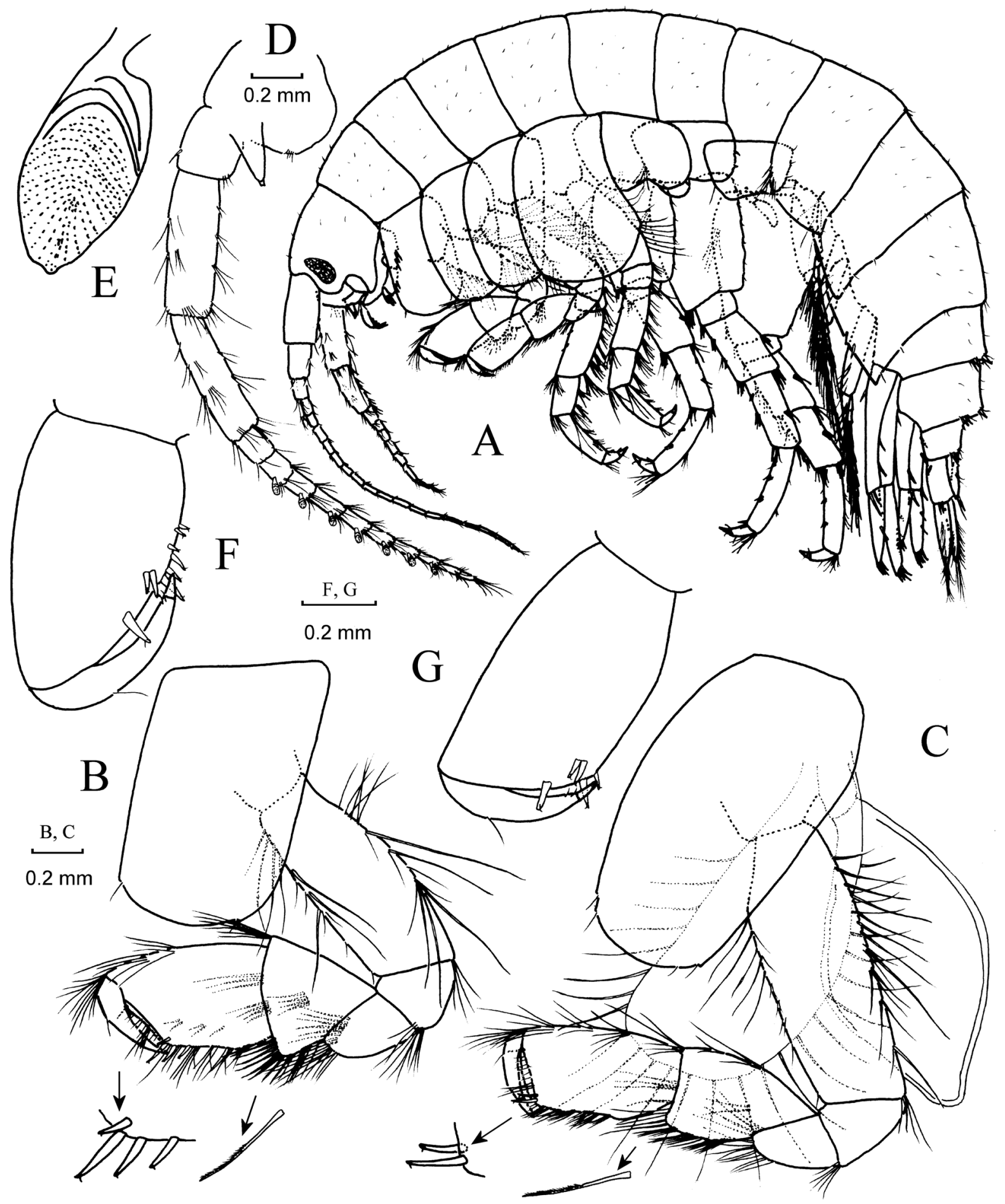

Fig. 2. Gammarus koshovi (Bazikalova, 1946), DAS 16-013. A-C. $\$, 8.0 \mathrm{~mm}$. A. Habitus, lateral view. B. Gnathopod I. C. Gnathopod II. - D-G. $0,7.5 \mathrm{~mm}$. D. Antenna II. E. Antenna II, calceolus $(\times 2800)$. F. Gnathopod I, setation omitted. G. Gnathopod II, setation omitted. 


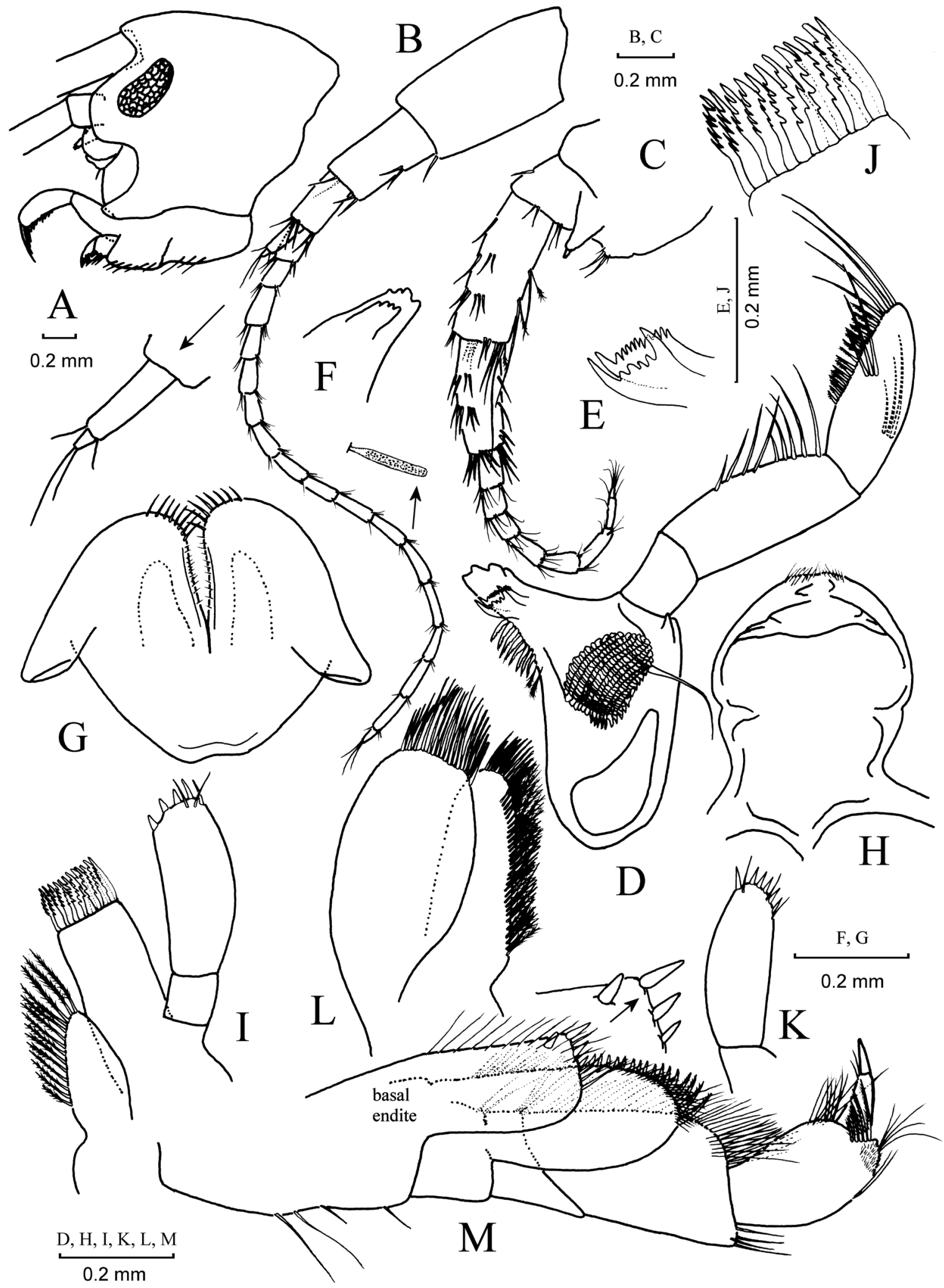

Fig. 3. Gammarus koshovi (Bazikalova, 1946), DAS 16-013,, , $8.0 \mathrm{~mm}$. A. Head. B. Antenna I. C. Antenna II. D. Mandible, right. E. Mandible, lacinia mobilis $(\times 600)$. F. Mandible, left (part.). G. Lower lip. H. Upper lip. I. Maxilla I, right. J. Maxilla I, outer plate $(\times 600)$. K. Palp of maxilla I, left. L. Maxilla II. M. Maxilliped. 


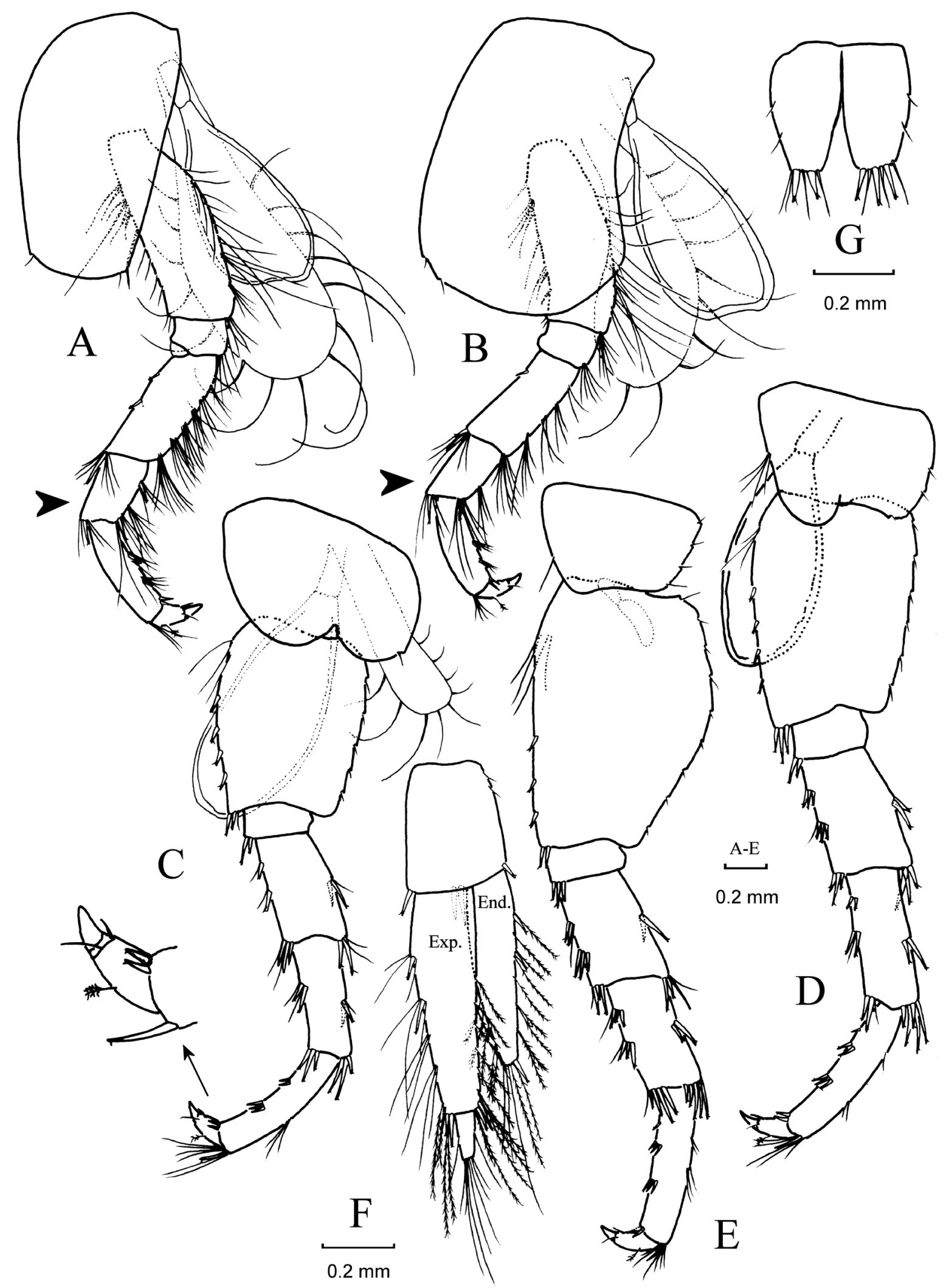

Fig. 4. Gammarus koshovi (Bazikalova, 1946), DAS 16-013. A-E., $8.0 \mathrm{~mm}$. A. Pereopod III. B. Pereopod IV. C. Pereopod V. D. Pereopod VI. E. Pereopod VII. - F-G. Ō, 7.5 mm. F. Uropod III. G. Telson. Black arrowheads indicate reduced carpi. 
with convex posterior margins, tapering distally, with 3 small spines and a tuft of setae along anterior and over 9 small setae along posterior margin; articles $4-5$ with 4 or 5 pairs of paired spines along margins; dactylus ca $35 \%$ of propodus (article 6 ) length, with a short nail.

PleOPODS AND UROPODS (Fig. 5C-H). Pleopods ordinary, rami subequal in length, segmented with 12-14 articles and fringed with plumose setae; peduncle with groups of thin setae, each retinacula two-hooked, accompanied by 1-2 slender simple stiff setae. Uropods I-II peduncles approximately reaching the end

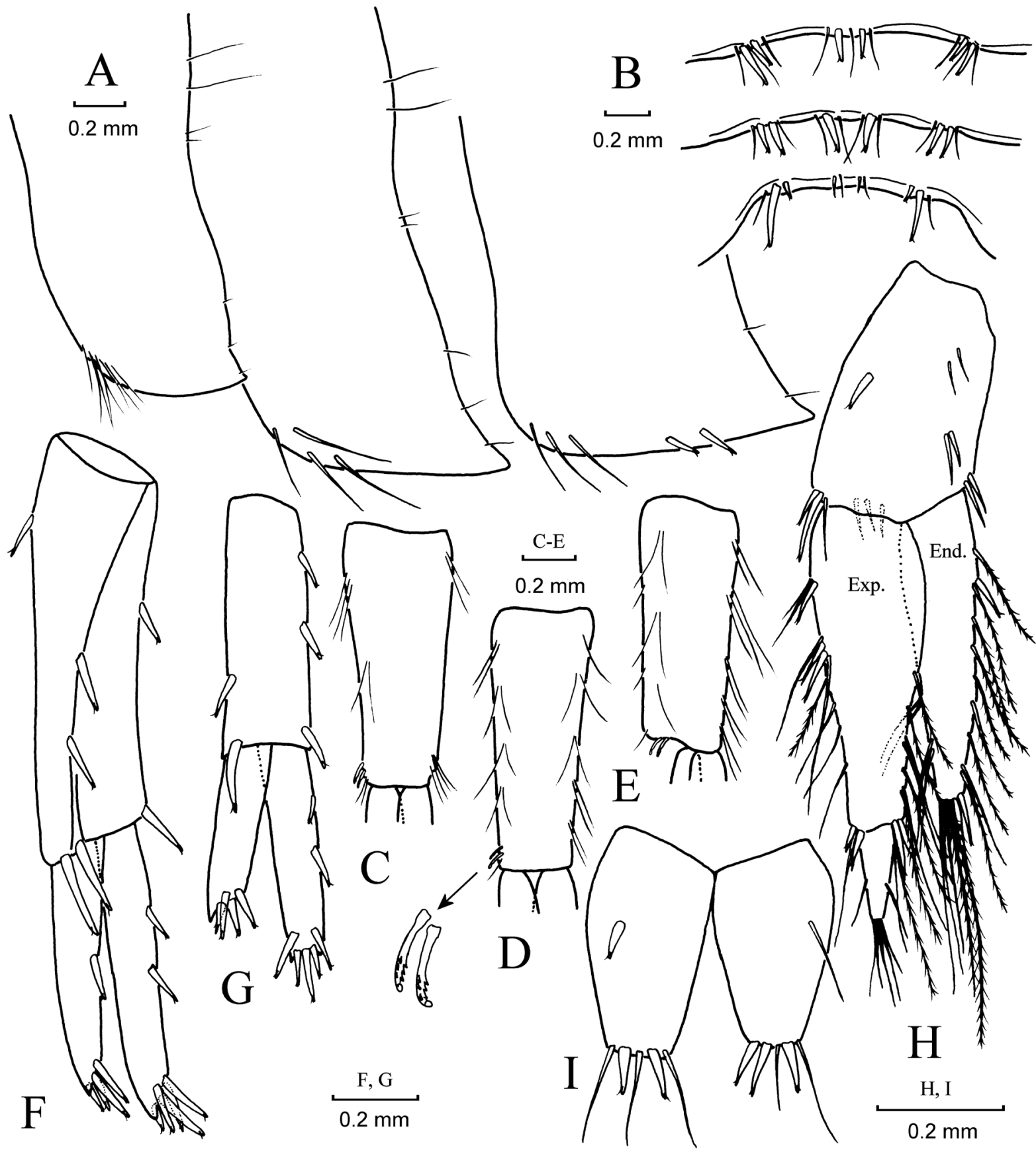

Fig. 5. Gammarus koshovi (Bazikalova, 1946), DAS 16-013,,$+ 8.0 \mathrm{~mm}$. A. Epimeral plates I-III. B. Urosoma, dorsal view. C-E. Pleopods I-III (part.). F. Uropod I. G. Uropod II. H. Uropod III. I. Telson. 
of uropod III peduncle, uropod I rami slightly beyond end of uropod III; peduncles with ca 4 or 6 spines along edges, uropod I with 1 basofacial spine, with 1 or 2 single spines along rami, with 3 apical and 2 subapical spines. Uropod III peduncle with 1 facial spine and 4 stiff setae and ca 8 weak spine-setae on apical margin; endopodite (= inner ramus) comprises $90 \%$ of exopodite (= outer ramus) length, with cluster of 1 spine and very long setae apically; terminal article of exopodite long, with tuft of short setae apically; both rami with moderately dense marginal brushes with mix of relatively long simple and plumose setae.

\section{Male}

Single, apparently subadult male, with habitus smaller $(\mathrm{BL}=7.5 \mathrm{~mm})$ and more slender; flagellum of antenna II with 10 articles, each with calceoli of gammarid type (type 1) (Lincoln \& Hurley 1981); gnathopods subsimilar to those of female, but propodi heavily armed at defining angle, each palm bearing 1 mid-palmar spine; uropod III weakly fringed with setae; in all other characters similar to female.

\section{Variation}

Not observed.

\section{Taxonomic remarks}

The enigmatic G. koshovi (Bazikalova, 1946) was collected in Lake Khubsugul of northeastern Mongolia (Fig. 1) and was reported in several previous publications (see Erbaeva et al. 1990; Safronov 2006; Dulmaa 2009), which has now necessitated a comparative study of this species with that in the remote Tore-Khol population of the Uvs Nuur Basin. Gammarus koshovi from Khubsugul was described rather superficially; a holotype was not deposited, which complicates detailed comparison. Furthermore, actual sampling of the Khubsugulian gammarids was not possible for correct comparisons. Although the original G. koshovi vs that in the Tore-Khol population exhibit differences, their pattern and variability are not clear (Table 1). Nevertheless, we consider these two forms to be closely related and belonging to the same lineage and united by the following: common fossorial morphotype (compact body, abbreviated antennae, spacious coxal plates, and strong, short pereopods with robust dactyli), presence of calceoli in antenna II of males, armament and gnathopod shape in both sexes, armament of urosomal segments, furnishing of pereopods, uropods, and telson. Bazikalova (1946) ignored the morphology of the carpi of pereopods III and IV. Additionally, her indication that antenna I comprised $25 \%$ of the entire body

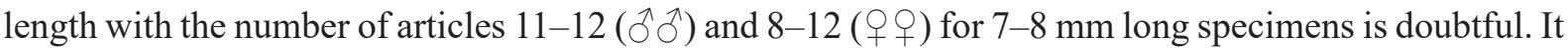
should be noted that G. koshovi is related to Gammarus sp. in Gurjanova (1930) described from Yenisey's riffle (downstream of Krasnoyarsk) based on several juvenile specimens with well-developed marsupial plates. Gurjanova (1930) compared the Yenisey form with juveniles of G. pulex (= G. lacustris G.O. Sars, 1863) from Karelia and the Polar Urals (see also Kessler 1868) and found them sharply different. Among the Central Asian members of Gammarus (Martynov 1935), the Tuvan-Mongolian G. koshovi, because of its small size, gravitates to a poorly distinguishable species from the springs of Turkestan, but the forms described by Martynov, despite their small size, still possess elongated antennae and not shortened pereopods, and are clearly distinguishable by their reduced eyes (see also Gammarus parvioculatus Sidorov, Hou \& Sket, 2018 in Sidorov et al. 2018: 445). Furthermore, there is no close similarity with species of the highly diversified Altay and Tian-Shan group of Gammarus (Zhao et al. 2017; Zheng et al. 2020). This indicates that the territory of Siberia/Mongolia, possibly the basin of the middle Yenisey, is inhabited by a small burrower-like form of Gammarus, the origin and phylogenetic relationships of which are unresolved.

\section{Accompanying fauna}

Mollusca, Ostracoda (subfossil, represented by separate valves), Coleoptera, larvae of Chironomidae and Ephemeroptera. 
Table 1. Comparison of character differences of Gammarus koshovi (Bazikalova, 1946) from two lacustrine populations.

\begin{tabular}{|c|c|c|}
\hline \multirow{2}{*}{ Feature } & \multicolumn{2}{|r|}{ Locality } \\
\hline & Tore-Khol Lake & Khubsugul Lake \\
\hline Antenna I covers & $40 \%$ of body length & $25 \%$ of body length \\
\hline Antenna I, primary flagellum with & 19 ภ, 16-17우우 articles & 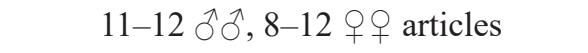 \\
\hline Antenna II, flagellum with & $10 \mathrm{O}^{\lambda}, 7-8$ 우 $ᄋ$ articles & 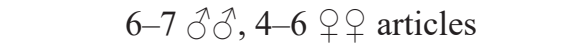 \\
\hline $\begin{array}{l}\text { Pereopods V-VII, along } \\
\text { posterior margins of basipodites }\end{array}$ & from 5 to 9 setae & from 14 to 16 setae \\
\hline Epimeral plates I-III & $\begin{array}{l}\text { I (set of setae disto-anteriorly), } \\
\text { II (setae disto-anteriorly), } \\
\text { III ( } 2 \text { spines) }\end{array}$ & $\begin{array}{c}\text { I (a row of setae along ventral margin), } \\
\text { II (setae cover } 2 / 3 \text { along ventral margin), } \\
\text { III (spines absent) }\end{array}$ \\
\hline Telson, lobes apically & with $2-3$ spines each & with 4 spines each \\
\hline
\end{tabular}

\section{Distribution and ecology}

Previously recorded from the area of Pupok Island in Khubsugul Lake (Fig. 1), a burrower-like gammarid form that dwells on silty sand at a depth of 15-16 m (Bazikalova 1946). Details of its biology in Khubsugul are lacking (Dulmaa 2009), but for Bazikalova to rely on the 'burrowing morphotype' implies its fossorial behavior. We have no direct observations of the burrowing behavior of the species, except that the samples were collected by bottom grabs in the Tore-Khol on muddy bald patches devoid of vegetation.

\section{Gammarus lacustris G.O. Sars, 1863}

Gammarus lacustris G.O. Sars, 1863: 207 (original description).

Gammarus pulex sibiricus - Kiseleva 1920: 15 (lakes of Ob' basin).

Gammarus pulex - Sars 1901: 133 (NE Mongolia); 1903: 233-261 (Siberia, Kazakhstan, Mongolia, Tibet). — Pirozhnikov 1929: 70 (Yenisey, upstream of Krasnoyarsk). — Lepneva 1930: 135 (around Biysk); 1933: 151 (Altay lakes). — Karaman 1991: 38 (see for full synonymy).

\section{Material examined (new records)}

RUSSIA - Tuva Republic $\cdot 3$ 우 (oostegites developed, some brooding the eggs), $15 \AA \widehat{\partial}(\mathrm{BL}=$ up to $14.0 \mathrm{~mm}$ ); small freshwater lake, southward of Shara-Nur Lake, near shepherd's camp; 50¹3'29.4" N, 94³2'32.1" E; 2-5 m depth; 12 Aug. 2011; E.N. Yalysheva leg.; yellowish silt, sapropelic mud with smell of hydrogen sulfide, plant residues (Phragmites australis); DAS 16-014 1 \& $(\mathrm{BL}=17.0 \mathrm{~mm})$; 'Dashtyg' taiga lake, upper reaches of Yenisey (source of Dashtyg-Aryg Stream), Todzha; 53⒉ $25^{\prime} 12.2^{\prime \prime} \mathrm{N}$, 9651'52.7" E; 0.5 m depth; 4 Aug. 2010; E.N. Yalysheva leg.; middle of lake, boulders, rubble, fouling, depressions between stones slightly silted; DAS 16-015.

\section{Remarks}

Considering the outstanding morphogenetic polymorphism (Sket et al. 2019) and the very wide distribution of Holarctic/Sino-Indian G. lacustris in the water bodies of Siberia (Tuva) and Mongolia (Fig. 1), it is highly probable that juveniles of this species can be misidentified as small species, such as G. koshovi. However, G. lacustris was absent in our samples from Tore-Khol, which we associated, first of all, with partial acidification of waters in the Russian part owing to the increased anthropogenic pressure because of intensive grazing, fishing, and other economic activities. It was previously reported that G. lacustris 
critically avoids water environments with $\mathrm{pH}<5$ (Moiseenko \& Yakovlev 1990). However, the exact reasons for this observation remain to be solved.

\section{Distribution and ecology}

Mostly inhabits the pluvial lakes of the region (Fig. 1), though it is also observed in lakes of the Baikal Rift Zone (previous indications in Baikal are accidental, in Stom \& Timofeev 1999; but see Vereshchagina et al. 2021). Kamaltynov (2009) reported the following data: common at depths of 0-7 m, on pebbles with sand and detritus, silted sand, flooded woods, remains of vegetation, and abundant in aquatic plant thickets. Inhabits thermal springs with temperatures up to $23^{\circ} \mathrm{C}$ and mineralization up to $340.5 \mathrm{mg} / \mathrm{L}$. Inhabits small lakes and rivers of the Baikal basin, in the Baikal and Transbaikal regions (including the Irkutsk and Bratsk reservoirs), adjoining water bodies of the Yenisey and Ob', lakes in the Vilyui region of Yakutiya, lakes in the interfluve of the Lena and Aldan rivers, Bauntovskye lakes, lakes in Mongolia (Khubsugul and Selenga basin, lakes and streams of Darhat Valley, Uvs Nuur Basin, Great Lakes Depression, and Valley of Lakes) (Dybowsky 1901; Sars 1901; Greze \& Greze 1958; Bezmaternykh 2008; Kamaltynov 2009; Østbye et al. 2018; Tolomeev et al. 2018). Paul (2012) indicated that G. lacustris inhabits the Mongolian part of Tore-Khol Lake.

\section{Key to the Siberian species of Gammarus (based on adults of both sexes)}

Gammarus barnaulensis Schellenberg, 1937 is not included in the key as the original description does not provide appropriate morphological features.

1. Body and appendages ordinary, length more than $8.0 \mathrm{~mm}$...................................................... 2

- Body compact, appendages shortened, length up to $8.0 \mathrm{~mm}$ (burrowing group *) .......................... 9

2. Species with dense setation on pereopods III-IV and uropod III (pulex group) ............................. 3

- Species with poorly setose pereopods III-IV and uropod III (balcanicus group) ............................ 8

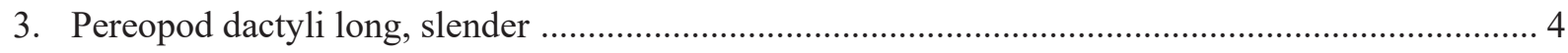

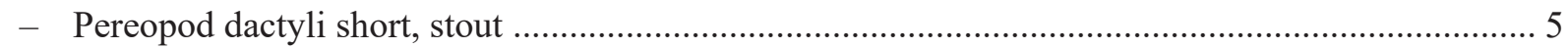

4. Urosomal segments moderately armed ……….................................... lacustris G.O. Sars, 1863

- Urosomal segments richly armed …………………………………....... G. hanhi Safronov, 2006

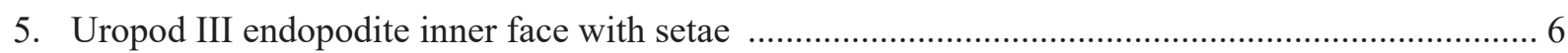

- Uropod III endopodite inner face naked ………………………….... G. teletzkensis Martynov, 1930

6. Epimeral plates II-III, ventral margins without setae, with spines .............................................. 7

- Epimeral plates II-III, ventral margins with a row of long setae ........G. angulatus Martynov, 1930

7. Antenna I slightly more than half of body length ............................. G. korbuensis Martynov, 1930

- Antenna I distinctly less than half of body length ....... G. dabanus Tachteev \& Mekhanikova, 2000

8. Antenna I, main flagellum up to 28 articles ....................................... G. angustatus Martynov, 1930

- Antenna I, main flagellum with 34-35 articles ................................... . pellucidus Gurjanova, 1930

9. Telson, lobes apically with 4 spines ..................................................... G. koshovi (Bazikalova, 1946)

- Telson, lobes apically with 1 or 2 spines .................................. Gammarus sp. in Gurjanova (1930)

* Conventionally proposed group to which we additionally assign Gammarus sp. in Gurjanova (1930). 


\section{Discussion}

During a detailed and comparative study of the lacustrine amphipod fauna in Inner Asia, a remote population of the poorly known Gammarus koshovi (Bazikalova, 1946), which was previously known only from the flowing Lake Khubsugul, was discovered. The history of lake formation in Inner Asia and the evolutionary transformations that they underwent are closely related to global processes throughout the Mesozoic-Cenozoic epoch (Gladkochub \& Donskaya 2009; Shuvalov 2013). Khubsugul Lake is the largest and deepest freshwater lake in Mongolia and the second largest (after Lake Baikal) in Inner Asia. It is associated with Baikal by a common origin and confinement to the Baikal Rift Zone, a common history of development, and modern 'arctic' runoff through the Egiin and Selenga Rivers (AOW - Arctic Ocean Watershed in Maasri \& Gelhaus 2012). The discovery of a small burrower-like form of the genus Gammarus raises a number questions, viz., why is G. koshovi absent in Baikal Lake and in other pools of its catchment area, and does it claim the role of a supposed ancestor for Palearctic forms? The burrowing lifestyle and special fossorial morphology is a fairly common phenomenon among marine amphipods, such as Haustoriidae Stebbing, 1906 (Bousfield 1970), as well as freshwater amphipods like the Baikal Micruropus Stebbing, 1899, Crypturopus Sowinsky, 1915 (Bazikalova 1962; Takhteev 2000), and the Caspian Pontogammarus Sowinsky, 1904, and Niphargoides G.O. Sars, 1894 (Copilaş- Ciocianu \& Sidorov 2021). However, it is rather unique for lacustrine amphipods of the genus Gammarus. Amongst 264 described species of the genus Gammarus, no lacustrine burrowing forms are known (Horton et al. 2021).

A number of endemic species in the Mongolian Khubsugul are prescribed a common genetic relatedness with the Baikalian groups. However, this has not been confirmed for gammarids, indicating their independent origin in these lakes (Kozhova et al. 2000; Goulden et al. 2006). Khubsugul has a less diverse set of biotopes and is much younger than Baikal, with the beginning of sedimentation expected to be no older than the Pliocene (Zorin et al. 1989). The ancient Mongolian multi-lake area in the Neogene is characterized by a developed lake-river system and is fed by numerous large rivers originating in the neighboring mountain structures of Khangai (Tes, Dzavkhan), Altay (Khovd, Bulgan), Khingan (Khalkhin), and Khentei (Kerulen) (Shuvalov \& Deviatkin 2013). Prozorova \& Zasypkina (2010) analyzed the distribution of Odhneripisidium Kuiper, 1962 and had the opinion that a shallow-water molluscan fauna formed in the flowing areas of the basin of a giant paleolake that existed in the Neogene up to the Late Pliocene (Florensov 1968). Herein, our original data for the Tore-Khol concerns only amphipods (2 spp.). However, it is known that the fauna of the lake is quite distinctive, although it mainly contains the typical inhabitants of the lentic environments of Inner Asia. Among others, the following elements are known: sponges (Spongillidae) (Wiens et al. 2009), taxonomically rich zooplankton (Flößner et al. 2005; Kirova et al. 2020), Oligochaeta, and amphibious Insecta (Trichoptera, Ephemeroptera, Chironomidae), mostly represented by taxa indicating a Palearctic distribution (Zaika \& Makarov 2000; Paul 2012). In numerous springs surrounding the lake, the following are common - Odonata, Plecoptera, Turbellaria, water boatman bugs (Corixidae), and water beetles (Dytiscidae) (Zaika 2011). Therefore, a couple of species are common to both lakes Tore-Khol and Khubsugul - Anisus (G.) terekholicus Prozorova \& Starobogatov, 1997, also known from Nogoon and Durgun Lakes, and the aforementioned G. koshovi (Bazikalova, 1946) (see Kozhova et al. 1994; Prozorova \& Starobogatov 1997; Sitnikova et al. 2011). The presence of the widespread amphipod G. lacustris in these lakes, as well the taxonomic status of the Khubsugulian G. hanhi Safronov, 2006, requires further confirmation.

An interesting observation by Belostotsky (1958) is that it is likely that from the Jurassic (Mesozoic) to the Pleistocene (Cenozoic) era, the upper part of the Yenisey basin was discharged into the Ubsunur system through the Samagaltay passage (located between Tannu-Ola Ridge and the western spurs of Sangilen Upland) (Fig. 1). This point of view is supported by a number of authors (Izzatullaev \& Starobogatov 1985; Tshernyshev 2010; Lukashov \& Smoktunovich 2018). However, based on some elusive similarity of the Yenisey Gammarus sp. in Gurjanova (1930) and G. koshovi, along with the unclear taxonomic status 
of the former, such an observation does not seem obvious. However, if the Yenisey acts as a 'faunistic donor' for the Ubsunur Basin, it is an interesting observation that the basin, as the largest endorheic basin (CAIW - Central Asian Inland Watershed in Maasri \& Gelhaus 2012), accumulates peripheral biodiversity.

It is well known that amphipods are amazingly plastic in terms of adaptations to various environmental conditions (they occupy all types of biotopes from oceanic trenches to the interstitial areas of sandy beaches and cave pools), show response to habitat drying (Gilbert et al. 2018), and have an effective ability to survive (Thorp \& Rogers 2011) and disperse (Rachalewski et al. 2013). The unlimited dispersal ability of epigean gammarids within drainage areas (Altermatt et al. 2014) in contrast to increased diversification rates due to isolation through mountain barriers (Hou et al. 2014), in combination with multiple rearrangements of the hydrographic networks of Inner Asia during the historical period (Zherikhin 2003; Zabelin \& Zaika 2021) could have positively affected the expansion of a species range. Therefore, we assume that upon careful research, G. koshovi will also be found in other lakes of the region.

Finally, we have concluded that an excessive presence of 'gray spots' in gammarid taxonomy significantly violates the accuracy of biogeographic information at a global scale. According to rough estimates, more than $80 \%$ of the described species of the genus Gammarus inhabiting the crucial region of Central Asia, Siberia, and the Far East need to be re-examined, and the number of undescribed species cannot be properly estimated.

\section{Acknowledgments}

We are grateful to B. Sket (Univerza v Ljubljani) and D. Scherbakov (LIN SB RAS) for their critical review of this manuscript and suggestions, and S. Krivonogov (IGM SB RAS), E. Govoruhina (ISU), L. Yanygina (IWEP SB RAS) and V. Zaika (TuvIENR SB RAS) for providing us with relevant literature. The authors thank topic editor and anonymous reviewers for comments on a previous version of this manuscript.

\section{References}

Altermatt F., Alther R., Fišer C., Jokela J., Konec M., Küry D., Mächler E., Stucki P. \& Westram A.M. 2014. Diversity and distribution of freshwater amphipod species in Switzerland (Crustacea: Amphipoda). PLoS ONE 9: e110328. https://doi.org/10.1371/journal.pone.0110328

Arakchaa L.K. \& Laidyp A.M. 1994. Redkiye i nuzhdayushchiyesya v okhrane rasteniya i zhivotnyye pustyn'i polupustyn’Ubsunurskoy kotloviny. KGPI Press, Kyzyl. [In Russian.]

Ayuushsuren Ch. \& Shcherbina G.Kh. 2015. Species composition and structure of macrozoobenthos in Lake Ulaagchny Khar (Mongolia). Inland Water Biology 8: 366-372.

https://doi.org/10.1134/S1995082915040045

Barnard J.L. 1958. Index to the families, genera and species of the gammaridean Amphipoda (Crustacea). Occasional Papers of the Allan Hancock Foundation 19: 1-145.

Barnard J.L. \& Barnard C.M. 1983. Freshwater Amphipoda of the World. Vol. 1, 2. Hayfield Associates, Mt. Vernon, Virginia.

Bate C.S. 1862. Catalogue of the Specimens of Amphipodous Crustacea in the Collection of the British Museum. Printed by order of the Trustees, London. https://doi.org/10.5962/bhl.title.20901

Bazikalova A.Ya. 1946. Amphipods of Lake Kossogol. Doklady Akademiyi Nauk SSSR 53: 673-675. [In Russian.] 
Bazikalova A.Ya. 1962. The systematics, ecology and distribution of the genera Micruropus Stebbing and Pseudomicruropus n.g. (Amphipoda, Gammaridea). In: Galazyi G.I. (ed.) Part1. Systematics and ecology of crustaceans of Baikal Lake. Trudy Limnologicheskogo Instituta Sibirskogo otdelenya AN SSSR 22: 3-140. [In Russian.]

Belostotsky I.I. 1958. Ocherki po istorii rel'yefa Tuvy. In: I.I. Belostotsky (ed.) Materialy po regional'noy geologii. Geologiya i geomorfologiya skladchatykh sooruzheniy Sibiri. Proceedings of the All-Union Aerogeological Trust 4: 149-186. [In Russian.]

Bezmaternykh D.M. 2008. Zoobenthos of the Upper Ob'River Tributaries. Altai State University Press, Barnaul. [In Russian.]

Bousfield E.L. 1970. Adaptive radiation in sand-burrowing amphipod crustaceans. Chesapeake Science 11: 143-154. https://doi.org/10.2307/1351237

Brandt J.F. 1851. Krebse. In: von Middendorff A.Th. (ed.) Dr. A.Th. von Middendorff's Reise in den äussersten Norden und Osten Sibiriens. Wirbellose Thiere: Annulaten, Echinodermen, Insekten, Krebse, Mollusken, Parasiten 2: 79-148. Kaiserlichen Akademie der Wissenschaften, St.-Petersburg.

Copilaş-Ciocianu D. \& Sidorov D. 2021. Taxonomic, ecological and morphological diversity of PontoCaspian gammaridean amphipods: a review. bioRxiv 2021.01.21.427559: 1-36.

https://doi.org/10.1101/2021.01.21.427559

Culver D.C., Kane Th.C. \& Fong D.W. 1995. 5. The geography of Gammarus minus. In: Culver D.C., Kane Th.C. \& Fong D.W. (eds) Adaptation and Natural Selection in Caves: The Evolution of Gammarus minus: 69-117. Harvard University Press, Cambridge. https://doi.org/10.4159/harvard.9780674419070.c5

Dgebuadze Yu.Yu. (ed.) 2013. Limnology and Palaeolimnology of Mongolia. Vol. 60: Biological Resources and Natural Conditions of Mongolia. Second edition. Proceedings of the Joint Russian-Mongolian Complex Biological Expedition RAS and MAS, Moscow. [In Russian.]

Dgebuadze Yu.Yu., Dorofeyuk N.I. \& Krylov A.V. 2010. Contributions of Russian scientists to the research of aquatic ecosystems in Mongolia. Mongolian Journal of Biological Sciences 8: 59-69. https://doi.org/10.22353/mjbs.2010.08.07

Dolgin V.N. \& Yalysheva E.N. 2008. Zoobentos ozera Kup-Khol' (Tuva). Tomsk State University Journal 316: 188-191. [In Russian.]

Dulmaa A. 1979. Hydrobiological outline of the Mongolian Lakes. Internationale Revue der gesamten Hydrobiologie 64: 709-736. https://doi.org/10.1002/iroh.19790640602

Dulmaa A. 2009. Chapter 1. State-of-the-art on the fauna of Lake Khubsugul and water bodies in Darkhatskaya depression. In: Timoshkin O.A. (ed.) Index of Animal Species Inhabiting Lake Baikal and its Catchment Area 2. Basins and Channels of in the South of East Siberia and North Mongolia 1: 553-555. Nauka, Novosibirsk.

Dulmaa A. 2013. Studies on the community and quantity of lakes Uvs Nuur Basin. Proceedings of the Institute of Biology of the Mongolian Academy of Sciences 29: 24-28.

Dybowsky B.I. 1901. 50-letiye vostochno-sibirskogo otdela Imperatorskogo Russkogo geograficheskogo obshchestva 1851-1901. In: Korotneff A.A. (ed.) Yubileynyy sbornik 1. Fauna Baykala. Rezul'taty zoologicheskoy ekspeditsii 1900-1901 gg., snaryazhennoy pod rukovodstvom professora Universiteta Sv. Vladimira A.A. Korotneff 4: 1-76. Litho-printing house S.V. Kulzhenko, Kiev. [In Russian.]

Erbaeva E.A., Safronov G.P., Shoshin A.V. \& Varykhanova K.V. 1990. Gammarids of the mountain lake Khubsugul (Mongolia). In: Khmeleva N.N., Golubev A.P., Sokolova N.Yu. \& Roshchin V.E. (eds) Species in Area: Biology, Ecology, and Productivity of Water Invertebrates: 55-59. Belorussian Committee for the UNESCO program "Man and the Biosphere", Navuka i Tekhnika, Minsk. [In Russian.] 
Florensov N.A. 1968. Some specific features of large lake basins in southern Siberia and Mongolia. In: Zhuze A.P. \& Florensov N.A. (eds) Mesozoic and Cenozoic Lakes of Siberia: 59-73. Nauka, Moscow. [In Russian.]

Flößner D., Horn W. \& Paul M. 2005. Notes on the cladoceran and copepod fauna of the Uvs Nuur Basin (northwest Mongolia). International Review of Hydrobiology 90: 580-595.

https://doi.org/10.1002/iroh.200410782

Gerstfeldt G. 1858. Ueber einige zum Thiel neue Arten Platoden, Anneliden, Myriapoden und Crustaceen Sibirien's, namentlich seines östlichen Theiles und des Amur-Gebietes. Mémores présentés à l'Académie Impérial des Sciences de Saint-Pétersbourg par divers Savants et Lus dans ses Assemblées, St.-Petersburg 6: 259-296.

Gilbert H., Keany J. \& Culver D.C. 2018. Response of shallow subterranean freshwater amphipods to habitat drying. Subterranean Biology 28: 15-28. https://doi.org/10.3897/subtbiol.28.30700

Gladkochub D. \& Donskaya T. 2009. Overview of geology and tectonic evolution of the Baikal-Tuva area. In: Müller W.E.G. \& Grachev M.A. (eds) Biosilica in Evolution, Morphogenesis, and Nanobiotechnology. Progress in Molecular and Subcellular Biology 47: 3-26. Springer, Berlin, Heidelberg. https://doi.org/10.1007/978-3-540-88552-8_1

Gorodkov K.B. 1961. Prostejshijmikroproektor dlya risovaniya nasekomyh. Entomological Review 40: 936-939. [In Russian.]

Goulden C.E., Tumurtogoo O., Karabanov E. \& Mongontsetseg A. 2006. Chapter 1. The geological history and geography of Lake Hovsgol. In: Goulden C.E., Sitnikova T., Gelhaus J. \& Boldgiv B. (eds) The Geology, Biodiversity and Ecology of Lake Hövsgöl (Mongolia): 259-278. Backhuys Publishers, Leiden.

Greze V.N. \& Greze Y.I. 1958. Ozero Chagytay (k izucheniyu ozer Tuvinskoy ASSR). The All-Union Geographical Society Herald 90: 279-284. [In Russian.]

Gundriser A.N., Popkov V.K., Vereshchinskiy E.G., Gundriser V.A., Konovalova O.S. \& Popkova L.A. 1986. Biologicheskiye osnovy povysheniya ryboproduktivnosti vodoyemov Tuvinskoy ASSR. VINITI, Tomsk 4620-B86: 1-157. [In Russian.]

Gurjanova E.F. 1930. Ueber die Fauna der Crustacea-Malacostraca der Jenissej-Mündungen. Russiche hydrobiologische Zeitschrift 8: 285-299. [In Russian.]

Horton T. et al. 2021. World Amphipoda Database. Gammarus Fabricius, 1775. Available from http://www.marinespecies.org [accessed 28 Mar. 2021].

Hou Z. \& Sket B. 2016. A review of Gammaridae (Crustacea: Amphipoda): the family extent, its evolutionary history, and taxonomic redefinition of genera. Zoological Journal of the Linnean Society 176: 323-348. https://doi.org/10.1111/zoj.12318

Hou Z., Sket B., Fišer C. \& Li S.-Q. 2011. Eocene habitat shift from saline to freshwater promoted Tethyan amphipod diversification. Proceedings of the National Academy of Sciences 108: 14533-14538. https://doi.org/10.1073/pnas.1104636108

Hou Z., Li J. \& Li S.-Q. 2014. Diversification of low dispersal crustaceans through mountain uplift: A case study of Gammarus (Amphipoda: Gammaridae) with descriptions of four novel species. Zoological Journal of the Linnean Society 170: 591-633. https://doi.org/10.1111/zoj.12119

Izzatullaev Z.I. \& Starobogatov Y.I. 1985. Zoogeographic characteristics of the fresh-water mollusks in Central Asia and the problem of validity of the mountain-Asian subregion of the Palearctic. Zoologicheskyi Zhurnal 64: 506-517. [In Russian.] 
Kalnaya O.I., Zabelin V.I., Archimayeva T.P. \& Ayunova O.D. 2018. Ecology and biodiversity of border territories of Tuva and Mongolia. Bulletin of the Altai Branch of Russian Geographical Society 48: 33-48. [In Russian.]

Kamaltynov R.M. 2009. Amphipoda: Gammaroidea in Angara and Yenisei Rivers. In: Timoshkin O.A. (ed.) Index of Animal Species Inhabiting Lake Baikal and Its Catchment Area, 2. Basins and Channels in the South of East Siberia and North Mongolia 1: 297-329. Nauka, Novosibirsk. [In Russian.]

Karaman G.S. 1970. Contribution to the knowledge of the Amphipoda 25. Beitrag zur Kenntnis der Amphipoden. Kritische Bemerkungen über Echinogammarus acarinatus (S. Kar. 1931) und Echinogammarus stocki n. sp. Poljoprivreda i Šumarstvo, Titograd 16: 45-66.

Karaman G.S. 1991. Contribution to the knowledge of the Amphipoda 205. The survey of described and cited freshwater Gammarus species (Fam. Gammaridae) from Soviet Union with redescription of two taxa. Poljoprivreda i Šumarstvo, Titograd 37: 37-73.

Kessler K.F. 1868. Sistematicheskoye obozreniye rakoobraznykh, sobrannykh v puteshestvii po Onezhskomu ozeru. In: Kessler K.F. (ed.) Materials for the Knowledge of Onega Lake and Obnezhsky Krai, Mainly in the Zoological Sense: 77-101. Printing house of the Imperial Academy of Sciences, St.-Petersburg.

Kirova N.A. 2019. Stanovleniye gidrobiologicheskikh issledovaniy v Tuve. Notes of the Ust-Kamenogorsk Branch of the Kazakh Geographical Society, Ust-Kamenogorsk 13: 102-106. [In Russian.]

Kirova N.A., Sinev A.Yu. \& Chertoprud E.S. 2020. Taxonomic composition of zooplankton in the Ubsunur Basin State Nature Reserve (Tyva, East Siberia). The Bulletin of Irkutsk State University. Series Biology. Ecology 33: 26-47. [In Russian.] https://doi.org/10.26516/2073-3372.2020.33.26

Kiseleva E.F. 1920. Travel report for the faunistic survey of the Ob River basin. Proceedings of the Natural History Department of the Siberian Research Institute 1: 15-28. [In Russian.]

Kosterin O.E. \& Zaika V.V. 2011. Fauna of dragonflies and damselflies (Odonata) of Tuva. Amurian Zoological Journal 3: 210-245.

Kozhova O.M., Izmest'eva L.R. \& Erbaeva E.A. 1994. A review of the hydrobiology of Lake Khubsugul (Mongolia). Hydrobiologia 291: 11-19. https://doi.org/10.1007/BF00024235

Kozhova O.M., Erbaeva E.A. \& Safronov G.P. 2000. The benthic invertebrates of Lake Khubsugul, Mongolia. In: Rossiter A. \& Kawanabe H. (eds) Ancient Lakes: Biodiversity, Ecology and Evolution. Advances in Ecological Research 31: 97-124. Academic Press, Amsterdam.

https://doi.org/10.1016/S0065-2504(00)31009-1

Leontyev L.N. 1957. Natural Conditions of Tuva Autonomic Oblast. Tuva Complex Expedition, Nauka, Moscow. [In Russian.]

Lepneva S.G. 1930. Amphipoda. In: Lepneva S.G. (ed.) K izucheniyu donnoy fauny verkhney Obi. Zapiski Gosudarstvennogo gidrologicheskogo instituta 3: 135-136. GGI, Leningrad [St.-Petersburg]. [In Russian.]

Lepneva S.G. 1933. Donnaya fauna gornykh ozer rayona Teletskogo ozera. In: Behning A.L. (ed.) Issledovaniya ozer SSSR 3: 135-168. GGI, Leningrad [St.-Petersburg]. [In Russian.]

Lincoln R.J. \& Hurley D.E. 1981. The calceolus, a sensory structure of gammaridean amphipods (Amphipoda: Gammaridea). Bulletin of the British Museum (Natural History), Zoology 40: 103-116. Available from https://www.biodiversitylibrary.org/part/35964 [accessed 14 Sep. 2021]. 
Lukashov A.A. \& Smoktunovich T.L. 2018. Change the configuration of river basins under the influence of tectonics and climate. In: Borsuk O.A. \& Nemykin A.Ya. (eds) Ecological and Geographical Research in River Basins: 69-74. VGPU Press, Voronezh. [In Russian.]

Maak R.K. 1886. Vilyuiskii okrug Yakutskoi oblasti. A. Tranchel, St.-Petersburg. [In Russian.]

Maasri A. \& Gelhaus J. 2012. Stream invertebrate communities of Mongolia: current structure and expected changes due to climate change. Aquatic Biosystems 8: 2-13. https://doi.org/10.1186/2046-9063-8-18

MacDonald K.S., Yampolsky L. \& Duffy J.E. 2005. Molecular and morphological evolution of the amphipod radiation of Lake Baikal. Molecular Phylogenetics and Evolution 35: 323-343.

https://doi.org/10.1016/j.ympev.2005.01.013

Martens K. \& Segers H. 2009. Endemism in aquatic ecosystems. In: Likens G.E. (ed.) Encyclopedia of Inland Waters. Vol. 1: 423-430. Elsevier, Amsterdam. https://doi.org/10.1016/B978-012370626-3.00211-8

Martynov A.V. 1930. Amphipodous fauna of Teletskoe Lake and its origin. Izvestiya Gosudarstvennogo gidrobologicheskogo instituta 29: 123-128. [In Russian.]

Martynov A.V. 1935. Amphipoda Gammaridea of the running waters of Turkestan. Travaux de l'Institute Zoologique de l'Académie des Sciences de l'URSS 2: 411-508.

Matafonov P.V. 2014. Zoobentos nekotorykh ozer severo-vostochnoy chasti Mongolii. Advances in Current Natural Sciences 11: 137-138. [In Russian.]

Milne-Edwards H. 1840. Histoire naturelle des Crustacés: comprenant l'Anatomie, la Physiologie et la Classification de ces Animaux. Tom 3. Librairie encyclopédique de Roret, Paris.

https://doi.org/10.5962/bhl.title.16170

Misar Z. 1997. Mongolia. In: Moores E.M. \& Fairbridge R.W. (eds) Encyclopedia of European and Asian Regional Geology. Encyclopedia of Earth Science: 540-546. Springer, Dordrecht, the Netherlands. https://doi.org/10.1007/1-4020-4495-X_71

Moiseenko T.I. \& Yakovlev V.A. 1990. Antropogennoye preobrazovaniye vodnykh ekosistem Kol'skogo Severa. Nauka, Leningrad [St.-Petersburg]. [In Russian.]

Ogarkov O.B., Kamaltynov K.M., Belikov S.I. \& Shcherbakov D.Y. 1997. Phylogenetic relatedness of the Baikal lake endemial amphipodes (Crustacea, Amphipoda) deduced from partial nucleotide sequences of the cytochrome oxidase subunit III genes. Molecular Biology 31: 24-29.

Østbye K., Østbye E., Lien A.M., Lee L.R., Lauritzen S.-E. \& Carlini D.B. 2018. Morphology and life history divergence in cave and surface populations of Gammarus lacustris (L.). PLoS ONE 13: e0205556. https://doi.org/10.1371/journal.pone.0205556

Paul M. 2012. Limnological Aspects of the Uvs Nuur Basin in Northwest Mongolia. Dissertation zur Erlangung des akademischen Grades Doctor rerum naturalium (Dr. rer. nat.), Fakultät Umweltwissenschaften, Dresden.

Pirozhnikov P.L. 1929. Zur Erforschung des Benthos des Jenissej-Stromes. Russ. Russiche hydrobiologische Zeitschrift 8: 68-73. [In Russian.]

Prokin A.A., Tsvetskov A.I., Seleznev D.G. \& Sazhnev A.S. 2019. Macroinvertebrates of fluctuating lakes in Mongolia. Ecosystem Transformation 2: 3-15. https://doi.org/10.23859/estr-190328

Prozorova L.A. \& Starobogatov Ya.I. 1997. New species of the subgenus Gyraulus of the genus Anisus and Choanomphalus (Gastropoda, Planorbidae). Ruthenica (Russian Malacological Journal) 7: 39-50.

Prozorova L.A. \& Zasypkina M.O. 2010. Discovery of living bivalves Odhneripisidium (Tuvapisidium) (Bivalvia: Pisidiidae). The Bulletin of the Russian Far East Malacological Society 14: 21-29 [In Russian.]. 
Rachalewski M., Banha F., Grabowski M. \& Anastácio P.M. 2013. Ectozoochory as a possible vector enhancing the spread of an alien amphipod Crangonyx pseudogracilis. Hydrobiologia 717: 109-117. https://doi.org/10.1007/s10750-013-1577-7

Safronov G.P. 2006. Chapter 13. Gammaridae of Lake Hövsgöl. In: Goulden C.E., Sitnikova T., Gelhaus J. \& Boldgiv B. (eds) The Geology, Biodiversity and Ecology of Lake Hövsgöl (Mongolia): 201-216. Backhuys Publishers, Leiden.

Sanders A.J.K., Harris Ch.D. \& Lattimore O. 2021. Mongolia. Encyclopedia Britannica. Available from https://www.britannica.com/place/Mongolia [accessed 14 Mar. 2021].

Sars G.O. 1863. Beretning om en i Sommeren 1862 foretagen zoologisk Reise i Christianias og Trondhjems Stifter. Nyt Magazin for Naturvidenskaberne 12: 193-340.

Sars G.O. 1901. On the crustacean fauna of Central Asia. Part 1. Amphipoda and Phyllopoda. Annuaire du Musée Zoologique de l'Académie Impériale des Sciences de St.-Petersburg 4: 130-164.

Sars G.O. 1903. On the crustacean fauna of Central Asia. Appendix. Local faunae of Central Asia. Annuaire du Musée Zoologique de l'Académie Impériale des Sciences de St.-Petersburg 8: 233-264.

Schellenberg A. 1937. Kritische Bemerkungen zur Systematik der Süsswassergammariden. Zoologischer Jahrbücher, Abteilung für Systematik 69: 469-516.

Shcherbina G.Kh. \& Ayuushsuren Ch. 2007. Structure of macrozoobenthos in some Mongolian lakes. Inland Water Biology 2: 62-70.

Sherbakov D., Kamaltynov R.M., Ogarkov O.B., Väinölä R., Vainio J.K. \& Verheyen E. 1999. On the phylogeny of Lake Baikal amphipods in the light of mitochondrial and nuclear DNA sequence data. Crustaceana 72: 911-919. https://doi.org/10.1163/156854099503816

Shuvalov V.F. 2013. Palaeogeography of Mongolian lakes in the Mesozoic. In: Dgebuadze Yu.Yu. (ed.) Limnology and Palaeolimnology of Mongolia. Vol. 60: Biological Resources and Natural Conditions of Mongolia: 208-235. Proceedings of the Joint Russian-Mongolian Complex Biological Expedition RAS and MAS, Moscow. [In Russian.]

Shuvalov V.F. \& Deviatkin E.V. 2013. Palaeogeography of Mongolian lakes in the Paleogene and Neogene. In: Dgebuadze Yu.Yu. (ed.) Limnology and Palaeolimnology of Mongolia. Vol. 60: Biological Resources and Natural Conditions of Mongolia: 254-263. Proceedings of the Joint Russian-Mongolian Complex Biological Expedition RAS and MAS, Moscow. [In Russian.]

Sidorov D., Hou Z. \& Sket B. 2018. Three new remarkable amphipod species (Crustacea: Gammaridae) from springs and subterranean waters of Central Asia. Zootaxa 4444 (4): 437-461.

https://doi.org/10.11646/zootaxa.4444.4.5

Sitnikova T.Ya., Sheveleva N.G., Slugina Z.V., Evstigneeva T.D. \& Dulmaa A. 2010-2011. Short notes on species diversity and fauna productivity of Lake Hövsgöl. In: Timoshkin O.A. (ed.) Index of Animal Species Inhabiting Lake Baikal and Its Catchment Area. Vol. 2. Basins and Channels in the South of East Siberia and North Mongolia. Book 2. Guides and Keys to Identification of Fauna and Flora of Lake Baikal: 1429-1434. Nauka, Novosibirsk. [In Russian.]

Sket B., Sidorov D. \& Hou Z. 2019. What happened to the genus Gammarus (Crustacea: Amphipoda) in Central Asia. Acta Biologica Slovenica 62: 45-66.

Stebbing T.R.R. 1906. Amphipoda I. Gammaridea. Das Tierreich. Lfg. 21. Verlag von R. Friedländer und Sohn, Berlin. https://doi.org/10.5962/bhl.title.1224

Stock J.H. 1974. The systematics of certain PontoCaspian Gammaridae (Crustacea, Amphipoda). Mitteilungen aus dem hamburgischen Zoologischen Museum und Institut 70: 75-95. 
Stom D.I. \& Timofeev M.A. 1999. The avoidance response of Gammarus lacustris Sars of Baikal water. Siberian Journal of Ecology 6: 649-653.

Takhteev V.V. 2000. Trends in the evolution of Baikal amphipods and evolutionary parallels with some marine malacostracan faunas. In: Rossiter A. \& Kawanabe H. (eds) Ancient Lakes: Biodiversity, Ecology and Evolution. Vol. 31. Advances in Ecological Research: 197-220. Academic Press, Amsterdam. https://doi.org/10.1016/S0065-2504(00)31013-3

Takhteev V.V. 2019. On the current state of taxonomy of the Baikal Lake amphipods (Crustacea: Amphipoda) and the typological ways of constructing their system. Arthropoda Selecta 28: 374-402. https://doi.org/10.15298/arthsel.28.3.03

Takhteev V.V. \& Mekhanikova I.V. 2000. New species of the sideswimmers (Crustacea Amphipoda) from the mountain streams of Khamar-Daban ridge. Proceedings of the Biology and Soil Department of the Irkutsk State University 3: 115-123. [In Russian.]

Thorp J.H. \& Christopher R.D. 2011. Chapter 17. Aquatic sow bugs, scuds, and opossum shrimp: Subphylum Crustacea, Class Malacostraca, Superorder Peracarida. In: Thorp J.H. \& Christopher R.D. (eds) Field Guide to Freshwater Invertebrates of North America: 147-156. Academic Press, Amsterdam. https://doi.org/10.1016/B978-0-12-381426-5.00017-X

Tolomeev A.P., Shulepina S.P., Makhutova O.N., Ageev A.V., Drobotov A.V. \& Sushchik N.N. 2018. Taxonomic composition and biomass of zoobenthos in saline Lake Shira: shifts that happened in 65 years. Journal of Siberian Federal University, Biology 11: 367-383. https://doi.org/10.17516/1997-1389-0079 [In Russian.]

Tshernyshev S.E. 2010. The role of transit ways in species penetration into non-relevant landscape zones. Euroasian Entomological Journal 9: 599-606. [In Russian.]

Vereshchagina K., Kondrateva E. \& Mutin A., Jakob L., Bedulina D., Shchapova E., Madyarova E., Axenov-Gribanov D., Luckenbach T., Pörtner H.-O., Lucassen M. \& Timofeyev M. 2021. Low annual temperature likely prevents the Holarctic amphipod Gammarus lacustris from invading Lake Baikal. Scientific Reports 11: e10532. https://doi.org/10.1038/s41598-021-89581-x

Walther M., Horn W. \& Dashtseren A. 2020. Chapter 8. Uvs Nuur: A sentinel for climate change in eastern Central Asia. In: Mischke S. (ed.) Large Asian Lakes in a Changing World. Natural State and Human Impact: 235-257. Springer, Cham, Switzerland. https://doi.org/10.1007/978-3-030-42254-7

Wiens M., Wrede P., Grebenjuk V.A., Kaluzhnaya O.V., Belikov S.I., Schröder H.C. \& Müller W.E.G. 2009. Towards a molecular systematics of the Lake Baikal/Lake Tuva sponges. In: Müller W.E.G. \& Grachev M.A. (eds) Biosilica in Evolution, Morphogenesis, and Nanobiotechnology. Progress in Molecular and Subcellular Biology 47: 111-144. Springer-Verlag, Berlin, Heidelberg. https://doi.org/10.1007/978-3-540-88552-8_5

Yalysheva E.N. 2010. Raspredeleniye zoobentosa v presnovodnykh ozerakh Tuvy. In: Lebedev V.I. \& Mamash E.A. (eds) Upravleniye resursnym potentsialom regionov na baze geoinformatsionnykh tekhnologiy: 17-112. TuvIENR SB RAS Press, Kyzyl. [In Russian.]

Zabelin V.I. \& Zaika V.V. 2021. Hydrographic connection of the paleo-Ulug-Hem with the basins of Mongolian's rivers and Amur River. Bulletin of the Russian Geographical Society 153: 19-31. [In Russian.] https://doi.org/10.31857/S0869607121010079

Zaika V.V. 1993. Biogidrotsenozy poverkhnostnykh vod Ubsunurskoy kotloviny. In: Lebedev V.I. (ed.) Prirodnyye usloviya i biologicheskiye resursy Zapadnoy Mongolii i sopredel'nykh regionov: 150-152. Ulaanbaatar. [In Russian.] 
Zaika V.V. 2011. Fauna i naseleniye amfibiontnykh nasekomykh (Insecta, Ectognatha: Ephemeroptera, Plecoptera, Trichoptera, Odonata) vodnykh potokov Altaye-Sayanskoy gornoy oblasti. Abstract of Dissertation thesis, Tomsk, Russia. [In Russian.]

Zaika V.V. \& Makarov P.L. 2000. Gidrobiotsenozy ozera Tore-Khol' (tsentral'naya chast' Ubsunurskoy kotloviny, Tuva). In: Lebedev V.I. (ed.) State and Exploration of Natural Resources of Tuva and Adjacent Regions of Central Asia 3: 48-51. SB RAS Press, Novosibirsk. [In Russian.]

Zhao S., Meng K. \& Hou Z. 2017. Two new Gammarus species and a new name (Crustacea: Amphipoda: Gammaridae) from Northwest China. Zootaxa 4273 (2): 195-215.https://doi.org/10.11646/zootaxa.4273.2.3

Zheng Y., Hou Z. \& Li S. 2020. Gammarus liuruiyui sp. nov. (Amphipoda, Gammaridae), a new blind species from Tian Shan, China. Crustaceana 93: 1485-1501. http://doi.org/10.1163/15685403-00003939

Zherikhin V.V. 2003. Izbrannye trudy po paleoekologii i filotsenogenetike. KMK Press, Moscow. [In Russian.]

Zorin Yu.A., Tumtanov E.Kh. \& Arvisbaatar N. 1989. Structure of Cenozoic basins of the Prekhubsugul region from gravity data. Russian Geology and Geophysics 29: 130-136. [In Russian.]

Manuscript received: 24 April 2021

Manuscript accepted: 7 July 2021

Published on: 13 October 2021

Section editor: Rudy C.A.M. Jocqué

Desk editor: Radka Rosenbaumová

Printed versions of all papers are also deposited in the libraries of the institutes that are members of the EJT consortium: Muséum national d'histoire naturelle, Paris, France; Meise Botanic Garden, Belgium; Royal Museum for Central Africa, Tervuren, Belgium; Royal Belgian Institute of Natural Sciences, Brussels, Belgium; Natural History Museum of Denmark, Copenhagen, Denmark; Naturalis Biodiversity Center, Leiden, the Netherlands; Museo Nacional de Ciencias Naturales-CSIC, Madrid, Spain; Real Jardín Botánico de Madrid CSIC, Spain; Zoological Research Museum Alexander Koenig, Bonn, Germany; National Museum, Prague, Czech Republic. 